\title{
REVIEWS.
}

\section{TREATMENT BY DIET.}

\section{2nd Edition.}

By Clifford J. Barborka, M.D., \&c. T. B. Lippincott Company. 1935. Price 21s. net.

The appearance of a second edition after a period of only a little over a year is sufficient evidence that this volume has met a distinct want. This is perhaps not to be wondered at in an age when diet and dietetics are the cause of so much thought not only by the doctor but also by the patient himself. For those who wish a book of reference with details regarding the diet to be prescribed, and the reasons therefor, in metabolic disease and in diseases of the blood, the gastro-intestinal tract and kidneys, and not merely general considerations, the present volume can be confidently recommended. The varieties of menus under each heading form a special feature and should prove most welcome in avoiding any tendency to monotony which is often such a marked character of this method of therapy.

\section{TESTING CHILDREN'S DEVELOPMENT FROM BIRTH TO SCHOOL AGE.}

By Charlotte Buehler, Ph.D., and Hildegard Hetzer, Ph.D. Translated from first German Edition by HENRY Beaumont, Ph.D. George Allen and Unwin, Ltd. 1936. Price 12s. 6d. net.

It has been a general belief that it is not possible to measure the intelligence of the child under the age of three years. The work of Doctors Buehler and Hetzer shows, however, that this is not so, but they point out that the one essential for success is a natural environment, a factor which has not been given hitherto sufficient attention.

The book is divided into three partsthe first gives the history of the development and elaboration of the method; then there follows a description of the technique of applying the tests and their evaluation. The third part gives the details of the various tests suitable for each age period.
The volume is one which should be in the hands of all those who have to do with the care of children and to Dr. Beaumont are due grateful thanks for the English translation and making it available to a wider public.

\section{A TEXTBOOK OF ROENTGENOLOGY.}

By J. M. Harrison, M.B., Ch.M., D.M.R.E. pp. $x+888$. 238 Illustrations. Baillière Tindall \& Cox, Ltd. 1936. Price 45/-.

This big book represents a new line of approach in radiological literature. It covers the whole range of X-ray work, including both diagnosis and treatment. It differs in that there is no attempt to produce a picture gallery or atlas, or even just a description of appearances as seen in the film or on the screen. Throughout the whole book the author has kept before him the fact that X-rays can be used to demonstrate the pathology of the living in terms of shadows. The radiologist who endeavours to interpret these shadows must base his work on a knowledge of the actual pathological state of the tissues, and not merely train his visual memory in such a way that he is able to compare the radiograph in front of him with one which he has seen before. He must consider each shadow in terms of the physical and pathological states causing it.

There is a short introductory chapter on physics, but a longer one on radio-physiology and biology. Technical considerations are briefly touched upon. A chapter on inflammation shows how often it is possible by basic interpretation of shadows to predict what type of bacterial organism is causing the condition. Then follow chapters on the Heart, the Arteries, the Blood and Blood-Forming Organs, the Spleen, the Ductless Glands, the Respiratory Tract, the Alimentary Tract, the Liver, the Gall Bladder and Pancreas, and the other systems including Ear, Eye, Nose and Skin. Each chapter considers seriatim 